\title{
Comparison of Physical and Motoric Features of Children Continuous the Sport School
}

\author{
Özgür Nalbant \\ Correspondence: Özgür Nalbant, Istanbul Gedik University, Turkey.
}

Received: November 15, 2017

Accepted: December 10, 2017

Online Published: December 13, 2017

doi:10.11114/jets.v5i13.2863

URL: https://doi.org/10.11114/jets.v5i13.2863

\begin{abstract}
Objective: The comparison of the physical and motoric features of the children continuous sport school within team sports.

Method: A total of 60 male athletes from 9 to 10 years participated as volunteers in the Galatasaray Sports Club for three months in basketball and volleyball. 27 of these athletes were basketball players and 33 were volleyball players.

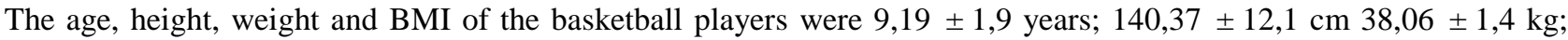
$18.71 \pm 3.7 \mathrm{~kg} / \mathrm{m}^{2}$ and the volleyball players were $10.54 \pm 1.6$ years,; $145.57 \pm 10.5 \mathrm{~cm} ; 41,34 \pm 1,4 \mathrm{~kg} ; 19,22 \pm 3,3 \mathrm{~kg}$ $/ \mathrm{m}^{2}$ respectively. The body mass index (BMI), which measures the height and body weight of the participants, was calculated. For the evaluation of the motoric properties, sit and reach, trunk lifting, hand grip, ball throwing, push-up, shuttle, $10 \mathrm{mt}$ speed, T test for agility, was tested. The SPSS 20.0 statistical program was used in the evaluation of the data. Independent Samples T Test was performed to compare the obtained data.
\end{abstract}

Findings: Significant difference was found sit and reach, body lifting and ball throwing in volleyball and was found 10 $\mathrm{m}$ speed in basketball $(\mathrm{p}<0,05)$.

Conclusion: Although some motoric features give different results in children going on to basketball and volleyball sports school, it has been found that they show similar features in most cases.

Keywords: basketball, volleyball, physical features, motoric features, sports school

\section{Introduction}

In parallel with the change of environmental and social culture structures in our country, it is observed that families prefer popular sports in directing their children to sport. Since sport plays an important role in the multifaceted development and socialization of the child, it is recommended to start the sport at early ages (Muratl1, 1998). According to Gallahue's hourglass model, children aged 7-10 years are in the transition phase to "sports skills", the first phase of sports-related movements. This is the stage where basic mobility skills need to be applied in more complex and specific ways, and it is necessary to allow the child to actively explore and combine multiple mobility skills (Galalhue et al., 2012). However, contrary to the research, the 9 to 10 year process is the years of expectation of academic achievement of the children of their families. The expected role of the child in this period, which is the transition period from primary education to secondary education, is to ensure success in academic field rather than regular sport participation. Studies conducted on the subject indicate that the academic achievement of children and young people with regular participation in sports is high. Singh et al. (2012) evaluated approximately 12,000 participants in their study of physical activity participation and academic achievement of children and adolescents between the ages of 6 and 18, and as a result reported a positive relationship between physical activity and academic achievement.

The sporting activities that children have done are important in terms of sporting performance as well as being effective in the development of physical, physiological and biomotorical features. The physical working capacity of children naturally develops over time with a certain degree of turn. Biomorphological properties are regarded as the basic mobility characteristics of man. These are durability, strength, speed, mobility, flexibility and coordination (Köylü, 2001). Naturally, physical and physiological structure is also important in terms of their ability to act. The fact that the physiological capacity of the physical structure is high with its original compatibility with the block is an important criterion for performance (Gürses \& Olgun 2005). 
One of the factors that affect performance is the bodily structure, in other words the physical characteristics. Because bodily structure or physical properties affect the presentation of physiological capacities. It is not possible to attain the desired performance level unless the physical structure possessed is suitable for the sport. The physical structure is only one of the indicators that an athlete can perform at a high level and it combines with the motoric characteristics and affects the performance of the athlete positively (Şenel et al., 2009). Today, in all branches, the faster, more capable, anthropometric and physiological capacities of athletes need to be superior to each other (Ersöz et al., 1996).

Age of 9-10, the period of childhood basic movements, also takes place during the period of sports related movements (Larson \& Zaichkowsky, 1995). In this period, the physical characteristics of the children should be determined and their suitability assessed. This issue is also the subject of research on the origin of health problems in adults (Pate et al., 2002, Fletcher et al., 1996). The other issue is the use of physical properties in evaluating talent. This is also the first step towards the creation of sub-structures and the training of elite athletes (Pate et al., 2002). Children need to participate in a number of tests to select the talent that needs to be done in a planned and systematic way (Balc1 et al., 2009, Freedson et al., 2000). School-age youth should participate daily in 60 minutes or more of moderate to vigorous physical activity that is developmentally appropriate, enjoyable, and involves a variety of activities (William et al., 2005). Motor proficiency is positively associated with physical activity and children's motor proficiency may be an appropriate target for increasing physical activity in youth (Brian et al., 2006). But children's physical activity levels were highly variable among preschools, which suggests that preschool policies and practices have an important influence on the overall activity levels of the children the preschools serve(Russell, et al., 2004). In addition, the children living in the urban areas were more inactive and obese, which resulted in a decrease in their flexibility and muscle endurance fitness (Ozdirenç et al., 2005).

Team sports are characterised by intermittent activities, in which intensive efforts are carried out over short time periods that alternate with periods of low intensity. This intermittent feature requires the use of all three energy systems (aerobic, lactic anaerobic and alactic anaerobic) to meet the players' metabolic demands. Moreover, these sports have complex demands that require a combination of individual skills, teamwork, technique, tactics and strategies, which contribute to the physical conditions of the players as well as the dynamic nature of team sports, in general Basketball has become one of the most popular sports in many countries. Performed a literature review on the physical abilities required to play basketball and defined it as a high-intensity sport with significant physical contact, high speed and constant jumps and shifts (both to attack and to defend). As a result, the main features of general physical fitness involved in basketball are anaerobic endurance and speed of movement. Other authors have added agility as a key factor in this sport. The characteristics of volleyball, including speed, jumping for spikes and blocks at high intensities over a short period of time result in fast and agile athletes who possess a high level of muscular strength and aerobic fitness. Adolescents are selected for this sport based on their skills, performance levels, physique and muscular strength (Silva, 2013).

Heart-respiratory system resistance includes muscular endurance, muscle strength, speed, flexibility, agility, balance, reaction time and body composition. These qualities are called performance-related physical fitness and health-related physical fitness (Fox 1999; Ozer 2001; Koç \& Aslan, 2010). Tests for team sports or individual sports will be conducted by athletes and sportswear, as well as sports and individual sports will contribute to the selection of the school.

The aim of working in this direction; It is a comparison of the physical and motoric characteristics of children continuous sport school. This study has the following objective: to compare the physical and motoric features basketball and volleyball who practice team sports.

\section{Material Method}

\subsection{Research Group}

A total of 60 male athletes from 9 to 10 years old who volunteered to work in Galatasaray Sports Club for three months in basketball and volleyball. . 27 of these athletes were basketball players and 33 were volleyball players. Athletes who did not have any health problems to work, who were regularly engaged in work and whose permission was given by their parents, participated to the study.

The volunteers were present in the gym with sports clothes on the designated date. The tests were done in the morning. Prior to the motoric tests, measurements were made to determine the physical properties. The groups were tested after 10 minutes of warming and flexibility work. Before starting the tests, detailed information was given about working with volunteers.

\subsection{Measurement of Physical Properties}

Measurement of Body Length: The participant's feet were bare, the heels were adjacent, the body and head were measured and recorded vertically. The moving part of the stadiometry was brought to the top of the head, and the measurement was compressed up to the size of the hair and the measurement was recorded up to $1 \mathrm{~mm}$. During the 
measurement, participants were asked to breathe deeply and protect their upright position (Özer 2001).

Measurement of Body Weight: Participants were wearing shorts and t-shirts during the measurement and the weight measurement made with the scale was recorded with a precision of $0.1 \mathrm{~kg}$. (Özer 2001).

The body mass index was calculated using the formula $\mathrm{kg} / \mathrm{m}^{2}$.

\subsection{Measurement of Motoric Properties}

Sit and reach and trunk lift test: The athlete sat by his feet in front of the table for measurement. While he was in this position, he extended his body as far as possible, slowly pushed the table down and stopped at the end. The test is repeated twice and the best result is recorded as $\mathrm{cm}$. In the body lifting test, he volunteered to lay his hands on his face in the supine. He volunteered to wait until the upper part of his body was lifted as high as possible from his hips. The distance between the floor and the chin was measured with a ruler. The best of both measurements was recorded (Tamer 2000).

Hand strength test: The hand dynamometer (Takei, Japan) was adjusted according to your hand measurement and the arm was measured by applying force to the paw without bending it from the elbow. The measurements were recorded twice for both hands and the best results were recorded (Tamer 2000).

Standing long jumping test: During testing in the beginning of a steel metric placed on a line of subjects '0', the meter strip was centered between two feet. They wanted to jump the longest distance they could jump from the subjects. After the jump, the last points left of the subjects were determined and measured. In order for the measurements to be reliable, the subjects performed the test twice. The best measurement was recorded (Kamar, 2008).

10 Meter speed test: Photocell is placed at the beginning and end of $10 \mathrm{~m}$ track. Participants start a speed run $50 \mathrm{~cm}$ behind the start line. Two trials were conducted and the best score was recorded (Ozdemir 2013).

Shuttle test: Lying on the back, the hands are consolidated on the hand. The knees were placed in a pulled position (with the knees at 90 degrees), with the bases fully grounded. Towards the top, the elbows had to come forward and the knees were touched at the end of the move. During the entire movement, it was noted that the hands were joined to the ensemble. At the beginning of the movement again the shoulders were at the mind. Within 30 seconds, this movement was tried to be repeated as many times as possible (Kamar, 2008).

Push-up test: Participant's arms took a tense push-up position. The body was brought close enough to touch and the elbows in the starting position were brought back straight and stretched. The number of push-ups made for 30 seconds was recorded (Kamar, 2008).

Illinois agility test: A 5-pound test track lined on a straight line with a width of $5 \mathrm{~m}$, a length of $10 \mathrm{~m}$ and a width of $2 \mathrm{~m}$ in the middle part was established in the closed sports hall. The test consists of a slalom run between $40 \mathrm{~m}$ straight, 20 $\mathrm{m}$ long columns with $180^{\circ}$ turns every $10 \mathrm{~m}$. After the test track was prepared, a two-port photocell electronic stopwatch system was installed, measuring $0.01 \mathrm{~s}$ at the beginning and end with precision. The test was allowed to run 3-4 trials on the low temp after the demonstration was announced and the necessary explanations were made before the test. After that, the subjects performed 5-6 min warming and stretching exercises in their low temp. The subjects exited the starting line of the test track and the finish time was recorded in seconds. The test was performed on time (Hazir et al., 2010).

Statistics: The SPSS 20.0 statistical program was used to evaluate the data. The Shapiro-Wilk test was applied to determine whether the data showed a normal distribution, and it was determined that the data showed normal distribution. Independent Samples T Test was performed to compare among independent examples. Confidence interval was $95 \%$ and significance level was accepted as $\mathrm{p}<0,05$.

\section{Results}

Measurements were made at the stations created for the tests applied in the study. The age, height, weight and BMI of

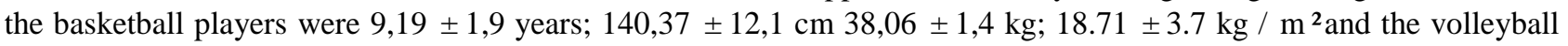
players were $10.54 \pm 1.6$ years,; $145.57 \pm 10.5 \mathrm{~cm} ; 41,34 \pm 1,4 \mathrm{~kg} ; 19,22 \pm 3,3 \mathrm{~kg} / \mathrm{m}^{2} \mathrm{respectively.} \mathrm{Age,} \mathrm{weight,} \mathrm{and}$ BMI were found to be better volleyball than basketball players in the measurements. However, no significant difference was found between the test values of basketball players and volleyball players $(p>0,05)($ Table 1$)$. 
Table 1. Physical properties of basketball and volleyball players

\begin{tabular}{llcc}
\hline $\begin{array}{l}\text { Basketball, } \mathrm{n}=27 \\
\text { Voleyball, } \mathrm{n}=33 \\
\text { Total, } \mathrm{n}=60\end{array}$ & & Mean & $\begin{array}{c}\text { Std. } \\
\text { Deviation }\end{array}$ \\
\hline Age & Basketball & 9,19 & 1,9 \\
& Voleyball & 10,54 & 1,6 \\
Height $(\mathrm{cm})$ & Basketball & 140,37 & 12,1 \\
& Voleyball & 145,57 & 10,5 \\
Weight $(\mathrm{kg})$ & Basketball & 38,06 & 13,4 \\
& Voleyball & 41,34 & 10,8 \\
BMI $\left(\mathrm{kg} / \mathrm{m}^{2}\right)$ & Basketball & 18,71 & 3,7 \\
& Voleyball & 19,22 & 3,3 \\
\hline
\end{tabular}

It was determined that the Sit and reach, trunk lifting, hand grip (right-left), ball throwing, shuttle and push-up test values were better in volleyball players, whereas the long jump, $10 \mathrm{~m} / \mathrm{s}$ speed and agility values were better in basketball players(Table 2). There was a significant difference hand grip strength, push-up, shuttle agility and standing long jump in volleyball. And was a significant difference $10 \mathrm{mt}$ speed test in basketball ( $\mathrm{p}<0,05)$.

Table 2. Physical properties of basketball and volleyball players

\begin{tabular}{|c|c|c|c|c|}
\hline Tests & Sport branch & Mean & Std. Deviation & Sig \\
\hline \multirow{2}{*}{ Sit and reach $(\mathrm{cm})$} & Basketball & 17,51 & 3,6 & \multirow{2}{*}{$0,00 *$} \\
\hline & Volleyball & 23,13 & 7,1 & \\
\hline \multirow{2}{*}{ Trunk lifting(cm) } & Basketball & 32,29 & 6,8 & \multirow{2}{*}{$0,01 *$} \\
\hline & Volleyball & 37,18 & 7,8 & \\
\hline \multirow{2}{*}{ Hand grıp(Right) } & Basketball & 15,41 & 5,4 & \multirow{2}{*}{0,62} \\
\hline & Volleyball & 17,13 & 4,9 & \\
\hline \multirow{2}{*}{ Hand grıp(Left) } & Basketball & 14,38 & 4,24 & \multirow{2}{*}{0,39} \\
\hline & Volleyball & 15,82 & 4,1 & \\
\hline \multirow{2}{*}{ Ball throwing $(\mathrm{cm})$} & Basketball & 307,40 & 10,2 & \multirow{2}{*}{$\mathbf{0 , 0 1 *}$} \\
\hline & Volleyball & 369,06 & 9,2 & \\
\hline \multirow{2}{*}{ Long jump $(\mathrm{cm})$} & Basketball & 128,62 & 12,6 & \multirow{2}{*}{0,44} \\
\hline & Volleyball & 127,16 & 11,2 & \\
\hline \multirow{2}{*}{$10 \mathrm{mt}$ Speed(sn) } & Basketball & 2,51 & 0,2 & \multirow{2}{*}{$0,00 *$} \\
\hline & Volleyball & 2,67 & 0,1 & \\
\hline \multirow{2}{*}{ Agility(sec) } & Basketball & 21,16 & 2,0 & \multirow{2}{*}{0,99} \\
\hline & Volleyball & 21,31 & 1,9 & \\
\hline \multirow{2}{*}{ Shuttle } & Basketball & 12,59 & 2,2 & \multirow{2}{*}{0,13} \\
\hline & Volleyball & 13,06 & 1,9 & \\
\hline \multirow{2}{*}{ Push-up } & Basketball & 6,66 & 0,4 & \multirow{2}{*}{$0,00 *$} \\
\hline & Volleyball & 9,12 & 1,8 & \\
\hline
\end{tabular}

$* \mathrm{P}<0,05$

\section{Discussion}

A total of 60 athletes who was 27 players in basketball and was 33 players in volleyball participated in this study, in order to compare the physical and motoric characteristics of the children continuous the sport school. The athletes did not have any health problems and volunteered to work. Their age and physical characteristics were suitable for their normal development.

Growth is affected by normal inheritance, physiological age, normal changes in nutritional status, health and hormone levels (MacGregor 2000). Physical and physiological tests applied to children are used to assess the effects of regular physical activity on growth, development and health, and to examine the trainability of children during adolescence (Docherty 1996).

Growth and maturation affect children's ability to acquire skills and motor performance. For this reason, it is necessary to understand how to grow and mature when researching children (Kosar \& Demirel, 2004, Siner et al., 2001). It is a perfect period to develop motor skills from 8 to 12 years and should not be missed (Kosar \& Demirel., 2004).

There was no difference in physical fitness between basketball players and volleyball players in our study. Kocahan and his colleagues also support our work in finding out the same end result in their work on these sport branches (Kocahan et al., 2017). In the study, boys aged 9-10 years who have been going to basketball and volleyball sports schools for about three months have been evaluated. There was no significant difference in grip strength, push-up, shuttle, agility and stopping long jump values compared to sports branches. Although Kalkavan and his colleagues compared 
basketball, volleyball and soccer players and sedanters in their studies, they stated that there is a significant difference between sedanter and sports group (Kalkavan et al., 1996). In addition, Koç and his colleagues emphasized the physical and motoric values of team sports, volleyball players and handball players (Koç et al., 2010).

On the other hand, according to the basketball players, there was a significant difference in the sit and reach, trunk lifting, ball throwing and push up tests in the volleyballs $(\mathrm{p}<0.05)$. The long muscles of the volleyball players gain and develop an even more flexible form with the flexibility exercises typical of sports. They include throwing a ball in the training context and specific exercises. As a result, volleyballs are thought to have the effect of flexibility and training content specific to sports (Aslan et al., 2015). On the contrary, a significant difference was found in favor of basketball in the $10 \mathrm{mt}$ speed test $(\mathrm{p}<0,05)$. The basketball-specific energy system, game structure and requirements have been influential in improving the speed of the athletes (Muratlı 2011). Koç and Kalkavan support our work when they study different or similar results in different sports branches (Koç et al., 2011, Kalkavan et al., 1996). In the study performed by Tsunawake and his colleagues, no difference in body measurements, body fold thickness or body composition between volleyball players and basketball players was observed (Tsunawake et al., 2003). On the other hand, Bayios and his colleagues point out that there is a difference between athlete in terms of body composition and somatotype characteristics in a study on volleyball, basketball and handball players (Bayios et al., 2006). In a study conducted by Yadav and his colleagues on basketball and volleyballs, they found no significant difference between the values of speed, skill, endurance and flexibility of 15-18 year old athletes (Yadav et al., 2016). In a study by Bhat, the findings also revealed that there was no significant difference in abdominal strength, endurance and lean body weight among the volleyball, handball and basketball players (Bhat, 2017).

The study is the first work in this age group in these sports. I have not had a job before. For this reason, it will help physical education and sports teachers and coaches determine children's abilities and direct their training programs.

\section{Conclusion}

As a conclusion, when the data obtained from this study were evaluated, a significant difference was found hand grip strength, push-up, shuttle agility and standing long jump in volleyball. And was a significant difference $10 \mathrm{mt}$ speed test in basketball. Parallel to the results of different studies, it was determined that some motoric traits in children who went to basketball and volleyball sports school show similar characteristics in spite of giving different results. This may indicate that similar studies have been conducted at different ages at different ages depending on the current methodology of training. The similarities in the study are thought to be due to the fact that the athletes are of the same age group and similar developmental periods. This phenomenon should be accepted as normal. Because, in the same age range, general sports perceptions will have similar results in similar team sports. For this reason, when participating in training in different sports, all players may have similar physical and motoric characteristics at the same age.

\section{References}

Aslan, C. S., Koç, H., \& Karakollukçu, M. (2015). Voleybol 1. Liginde Oynayan Erkek Sporcuların Seçilmiş Fiziksel, Fizyolojik Ve Motorik Özelliklerinin Belirlenmesi. İnönü Üniversitesi, Beden Eğitimi Ve Spor Bilimleri Dergisi, 2(3), 1-13.

Balcı, Ş. S., Pekel, H. A., Karakuş, S., Pepe, H., Revan, S., \& Bağcı, E. (2009). 9-11 Yaş Grubu İlköğretim Öğrencilerinin Performansla İlgili Fiziksel Uygunluklarının Değerlendirilmesi, Selçuk Üniversitesi Sosyal Bilimler Dergisi, 103-108.

Bayios, I. A., Bergeles, N. K., Apostolidis, N. G., Noutsos, K. S., \& Koskolou, M. D. (2006). Anthropometric, body composition and somatotype differences of Greek elite female basketball, volleyball and handball players. Journal of Sports Medicine and Physical Fitness; Turin, 46(2), 271-280.

Bhat, T. R. (2017). A comparison of health related physical fitness among volleyball, handball and basketball players. International Journal of Physiology, Nutrition and Physical Education, 2(1), 279-282.

Brian, H. W., Leonard, H. E., Joan, M. D., Katherine, E. J., \& Valerie, A. K. (2006). The Relationship between Motor Proficiency and Physical Activity in Children. Pediatrics, December 2006, 118(6).

Docherty, D. (1996). Measurement in Pediatric Exercise Science, Human Kinetics, 34-86.

Ersöz, G., Koz, M., Sunay, H., \& Gündüz, N. (1996). Erkek voleybol oyuncularının sezon öncesi, sezon ortası ve sezon sonu fiziksel uygunluk düzeyi parametrelerindeki değişmeler, Gazi Üniversitesi Beden Eğitimi ve Spor Bilimleri Dergisi, 1(4), 1-7.

Fletcher, G. G., Balady, G., Blair, S. N., Blumenthal, J., Caspersen, C. J., \& Chaitman, B. (1996). Statement on exercise: Benefits and recommendations for physical activity. Exercise and Cardiac Rehabilitation of the Council on Clinical Cardiology, American Heart Association. Circulation, 94, 857-862. https://doi.org/10.1161/01.CIR.94.4.857 
Fox, B. F. (1999). Physiological Foundation of Physical Education and Sports, Bağırgan Publication, 435.

Freedson, P. S., Cureton, K. J., \& Heath, G. W. (2000). Status of Field- Based Fitness Testing in Children and Youth, Preventive Medicine, 31, 77-85. https://doi.org/10.1006/pmed.2000.0650

Galalhue, D., Ozmun, J., \& Goodway, J. (2012). Understanding Motor Development: Infants, Children, Adolescents, Adults 7th Edition Copyright: 2012

Gürses, Ç., \& Olgun, P. (2005). Sportif Yetenek Araştırma Metodu (Türkiye Uygulaması), Türk SporVakfi

Hazır, T., Mahir, Ö. F., \& Açıkada, A. (2010). Genç Futbolcularda Çeviklik İle Vücut Kompozisyonu ve Anaerobik Güç Arasındaki İlişki. Spor Bilimleri Dergisi Hacettepe J. of Sport Sciences, 21(4), 146-153.

Kalkavan, A., Zorba, E., Ağaoğlu, S., Karakuş, S., \& Çolak, H. (1996). Farklı spor branşlarında bazı fiziksel uygunluk değerlerinin sedanter grupla karşılaştırılması. Beden Eğitimi ve Spor Bilimleri Dergisi, I(3), 25-35.

Kamar, A. (2008). Sporda Yetenek Beceri ve Performans Testleri. Nobel Yayın Dağıtım, Ankara.78-80.

Koç, H., \& Aslan, C. S. (2010). Erkek Hentbol Ve Voleybol Sporcularının Seçilmiş Fiziksel Ve Motorik Özelliklerinin Karşılaştırılması. Selçuk Üniversitesi Beden Eğitimi ve Spor Bilim Dergisi, 12(3), 227-231

Koç, H., Pulur, A., \& Karabulut, E. (2011) Erkek Basketbol Ve Hentbolcuların Bazı Motorik Özelliklerinin Karşılaştırılması. Niğde Üniversitesi Beden Eğitimi Ve Spor Bilimleri Dergisi, 5(1).

Kocahan, T., Akınoğlu, B., Soylu, Ç., Birben, T., \& Yıldırım, N. (2017). Tekerlekli Sandalye Basketbol Ve Plaj Voleybolu Sporcularının Omuz Fleksiyon Ve Ekstansiyon İzokinetik Kas Kuvvetlerinin Karşılaştırılması:Pilot Çalışma. The International Balkan Conference in Sport Sciences.

Kosar, N. Ş., \& Demirel, H. A. (2004). Çocuk Sporcuların Fizyolojik Özellikleri. ACTA Orthopaedica et Traumatologica Turcica suplementum, 1(38), 1-15.

Köylü, H., \& Fizyoloji, T. M. Isparta, 2001, 138.

Larson, G. A., \& Zaichkowsky, L. D. (1995). Physical Motor and Fitness Development in Children and Adolescents, Journal of Education, 177, 25-55.

MacGregor, J. (2000). Anatomy and Physiology of Children, Florence, USA: Routledge, 20-21.

Muratlı, S. (1998). Çocuk ve Spor, Bağırgan Yayımevi, Ankara, 60.

Muratlı, S., Kalyoncu, O., \& Şahin, G. (2011). Antrenman ve Müsabaka. Kalyoncu spor danışmanlık, İstanbul, 410-413.

Özdemir, M. (2013). Genç Futbolcularda Çeviklik, Sürat, Güç ve Kuvvet Arasındaki İlişkinin Yaşa Göre İncelenmesi. Yüksek Lisans Tezi.

Ozdirenç, M., Özcan, A., Akın, F., \& Gelecek, N. (2005). Physical fitness in rural children compared with urban children in Turkey. Physical fitness in rural children compared with urban children in Turkey. Pediatrics International, 47, 26-31. https://doi.org/10.1111/j.1442-200x.2004.02008.x

Özer, K. (2001). Fiziksel Uygunluk. Nobel Yayınevi. Ankara, 78-80.

Pate, R. R., Freedson, P. S., \& Sallıs, J. F. (2002). Compliance with Physical Activity Guidelines: Prevalence in a Population of Children and Youth, AEP, 12, 303-308.

Russell, R. P., Karin, A. P., Stewart, G. T., Paula, Z., \& Marsha, D. (2004). Physical Activity among Children Attending Preschools. Pediatrics, 114(5).

Şenel, Ö., Taş, M., Harmanc1, H., Akyüz, M., Özkan, A., \& Zorba, E. (2009) Güreşçilerde vücut kompozisyonu, anaerobik performans, bacak ve sırt kuvveti arasındaki ilişkinin belirlenmesi, Gazi Beden Eğitimi ve Spor Bilimleri Dergisi, $X I V(2), 13-22$.

Silva, D. A. S., Petroski, E. L., \& Gaya, A. C. A. (2013). Anthropometric and Physical Fitness Differences Among Brazilian Adolescents who Practise Different Team Court Sports. Journal of Human Kinetics, 36, 77-86.

Siner, R. N., Hausenblas, H. A., \& Janelle, C. M. (2001). Handbook of Sport Psychology, Second Edition, Newyork, USA, 44.

Singh, A., Uijtdewilligen, L., Twisk, J. W., van Mechelen, W., \& Chinapaw, M. J. (2012). Physical Activity and Performance at School: A Systematic Review of the Literature Including a Methodological Quality Assessment. Archives of Pediatrics and Adolescent Medicine, 166(1), 49-55. https://doi.org/10.1001/archpediatrics.2011.716

Tamer, K. (2000). Sporda fiziksel performansın ölçülmesi ve değerlendirilmesi. Bağırgan yayınevi Ankara, 163-169. 
Tsunawake, N., Tahara, Y., Moji,. K., Muraki, S., Minowa, K., \& Yukawa, K. (2003). Body Composition and Physical Fitness of Female Volleyball and Basketball Players of the Japan Inter-high School Championship Teams. Journal Phycial Anthropol Appl. Human Sci., 22, 195-201. https://doi.org/10.2114/jpa.22.195

William, B. S., Robert, M. M., Cameron, J. R. B., Stephen, R. D. Rodney, K. D., Bernard, G., ... François, T. (2005). Evidence Based Physical Activity for School-age Youth. The Journal of Pediatrics, 146(6), June 2005, $732-737$. https://doi.org/10.1016/j.jpeds.2005.01.055

Yadav, S. K. S., Yadav, M., \& Kerketta, I. (2016). Comparison of selected pyhsical fitness variables of school level basketball and volleyball male players. International Journal of Physical education and Sports, 1(3), 21-23.

\section{Copyrights}

Copyright for this article is retained by the author(s), with first publication rights granted to the journal.

This is an open-access article distributed under the terms and conditions of the Creative Commons Attribution license which permits unrestricted use, distribution, and reproduction in any medium, provided the original work is properly cited. 